Вісник Дніпропетровського університету. Серія: геологія, географія. 2016. 24 (1), 151-157.

Vìsnik Dnìpropetrovs'kogo unìversitetu. Serìa geologiâ, geographìâ

Dnipropetrovsk University Bulletin. Series geology, geography. 2016, 24 (1), 151-157.

doi: $10.15421 / 111623$

http://geology-dnu.dp.ua

УДК 556.332.4

\title{
Аналіз хімічного складу підземних вод водоносних горизонтів четвертинних відкладів території Північного гірничо-збагачувального комбінату (Кривбас)
}

\section{Н. П. Шерстюк, Л. О. Носова}

Дніпропетровський національний університет імені Олеся Гончара, Дніпропетровськ, Украӥна, e-mail: sherstuknp@inbox.ru; nosova.lud@gmail.com

Гірничодобувна промисловість чинить потужний вплив на довкілля. У районах видобутку корисних копалин відбуваються корінні зміни геологічного середовища, які є незворотними. Підземні води, як елемент чотири- компонентної гідрогеологічної системи, зазнають значних перетворень. Виконано дослідження хімічного складу підземних вод водоносних горизонтів четвертинних відкладів на території Північного гірничо-збагачувального комбінату. Дослідження базуються на результатах гідрогеологічного моніторингу, який проводить Криворізька геологогідрогеологічна партія 31978 року. Гідрогеохімічна інформація занесена у бази даних. Для подальших досліджень обрано результати моніторингу по 24 свердловинах, виконано обробку хімічних аналізів проб води, складено формули Курлова, індекси Алскіна. Встановлено, що найбільші зміни гідрогеохімічних умов відбуваються за увесь час спостережень на території проммайданчика, житлового масиву, у водоносному горизонті алювіальних відкладів заплави Саксагань. Виявлені основні природні та техногенні чинники, які впливають на формування хімічного складу підземних вод на території, що досліджується.

Ключові слова: гірничо-збагачувальний комбінат, підземні води, головні іони, гідрогеохімічні закономірності

\section{Analysis of the chemical composition of the groundwater aquifers of ŭuaternary sediments of the Northern mining and processing plant (Kryvbas)}

\author{
N. P. Sherstuk, L. A. Nosova \\ Oles Honchar Dnipropetrovsk National University, Dnipropetrovsk, Ukraine, \\ e-mail:sherstuknp@inbox.ru; nosova.lud@gmail.com
}

\begin{abstract}
Mining provides a powerful impact on the environment. In the areas of mining radical changes occurring geological environment that are irreversible. Groundwater, as part of the four component hydrogeological system undergo significant changes. The investigation of the chemical composition of groundwater aquifers of quaternary sediments in the North mining plant. The study is based on results of hydrogeological monitoring carried out geological and hydrogeological Krivorozhskiy party since 1978. Hydrogeochemical information entered in the database. For further research on selected results of monitoring 24 wells, processing performed chemical analysis of water samples drawn Kurlov formula, indexes Alyekina. Established that the changes in hydro conditions occur at all times of observations at the industrial site, residential area, the aquifer sediments of alluvial floodplain river Saksagan. The basic natural and man-made factors that influence the formation of the chemical composition of groundwater in the territory studied.
\end{abstract}

Keywords: mining and processing plant, groundwater, major ions, hydrogeochemical patterns

Вступ. Сучасна геологічна діяльність людини характеризується глобальними масштабами, високими швидкостями і різноманітністю форм прояву. 3 позицій сучасного рівня знань під техногенезом слід розуміти сукупність геохімічних, гідрогеохімічних, фізико-хімічних, біохімічних процесів, що відбуваються в біосфері за впливу інженерногосподарської діяльності людини.

Для досліджуваного району Криворізького залізорудного басейну суттєві порушення у розвитку природних умов зумовлені тривалим цілеспрямованим антропогенним впливом на один 3 основних компонентів ландшафту, яким $є$ природні води. Господарська діяльність тут пов'язана як із сільським господарством, так і 3 розробкою корисних копалин відкритим способом, із промисловістю, будівництвом і благоустроєм міст, а також з іншими видами діяльності людини.

Інтенсивність господарської діяльності безперервно зростала протягом останніх десятиліть i 
нині досягла максимальних величин (Mogilevskyi, 2002).

Гірничодобувна промисловість - один із потужних факторів техногенного перетворення геологічного середовища. На іï частку припадають значні площі земель, які частково або повністю втратили природну родючість і стали не придатними для проживання людей. У процесі розробки корисних копалин у Кривбасі були знищені окремі елементи природного ландшафту і сформований не властивий природі антропогенний ландшафт, представлений комплексом техногенних форм (різноманітність кар'єрів, виїмок, відстійників, штучних каналів, відвалів, гірничих виробок і т. д.).

Зараз у Криворізькому басейні відомо близько 300 покладів багатих залізних руд, які в межах басейну об'єднані в 25 родовищ. Деякі з них уже відпрацьовані. 3 початку освоєння басейну відпрацьовано 1700000000 т багатих руд, їх запаси за сумою промислових категорій до глибини 1500 м складають 1157 млн т, ще 231600000 т розвідано в інтервалах глибин від 1500 до 2000 м. Середній вміст заліза в них $-53,83$ \%. Нині на рудниках із підземним видобутком сировини роботи ведуться в інтервалах глибин $800-1350$ м, а підготовчі роботи - на граничних для існуючих технологій глибинах.

Смуга родовищ руди тягнеться у Кривбасі на відстань близько 100 км уздовж р. Інгулець і його приток - Саксагані та Жовтої. Ширина коливається від 0,5 до 3,0 км, а в центральній частині сягає 6 - 7 км. Уздовж цієї смуги розташовані кар'єри, копальні, гірничо-збагачувальні комбінати, металургійний завод, м. Кривий Ріг і робітничі селища (Sherstjuk, Evgrashkina, Vlasova, 2007).

Глибина найбільших кар'єрів із видобутку залізної руди перевищує 200 м.

Підземні води, як елемент гідрогеологічної системи, зазнають у процесі техногенезу істотних змін у гідродинамічному і гідрогеохімічному режимах.

Суть дослідження полягає у виявленні закономірностей змін гідрогеохімічного стану підземних вод водоносного горизонту четвертинних відкладів на території ПівГЗК з 1978 по 2015 рік.

Матеріали і методи досліджень. 31978 року Кріворізька геолого-гідрогеологічна партія на теритоpiї Кривбасу проводить гідрогеологічний моніторинг. Тісна співпраця гідрогеологів цієї партії та науковців геолого-географічного факультету ДНУ імені Олеся Гончара триває більше 25 років, як у виконанні господарчих договорів, так і в наданні поточних консультацій щодо організації та проведення гідрогеологічного моніторингу. У 1991 1995 рр. виконувалися госпдоговори зі створення та наповнення баз гідрогеологічних спостережень, у 2015 р. - виконано хімічні аналізи проб води із свердловин, які належать до мережі гідрогеологічного моніторингу території Кривбасу.

Найбільше гідрогеологічної інформації накопичено щодо території Північного гірничозбагачувального комбінату (ПівнГЗК).

На даному етапі, який є продовженням досліджень, розпочатих у 1991 р., виконано аналіз, співставлення, узагальнення наявної гідрогеохімічної інформації. Для цього використано основні правила обробки гідрохімічних даних: заповнення баз даних, розрахунок формули Курлова та індексу Алєкіна.

Результати та їх аналіз. У геологічному відношенні територія Північного гірничо-збагачувального комбінату складена четвертинними відкладами, пухкими породами неогенового і палеогенового віку, які залягають на первинних каолінах і кристалічних породах докембрію. Докембрійські кристалічні породи представлені гранітами і мігматитами, мають повсюдне поширення. Покрівля їх хвиляста, сильно еродована із загальним ухилом у південно-східному напрямку. Елювій кристалічних порід - каоліни, майже повсюдно залягають на кристалічних породах докембрію і породах криворізької метаморфічної серії. Представлені вони білими, сірувато-білими каолінітовими глинами, які $є$ водотривом для вищерозміщеного водоносного горизонту палеогенових відкладів.

Палеогенові відклади представлені глинами і пісками, насамперед глауконітовими сильно піскуватими глинами, які місцями переходять у тонкозернисті глинясті піски. Відклади мають обмежене поширення і заповнюють зниження в кристалічному фундаменті. Потужність відкладів досягає 5-8 м. Потужність пісків складає 6-20 м, зменшуючись на ділянці хвостосховища до 1,0 м. Залягають вони на еродованій поверхні каолінів. Виходи їх $\epsilon$ на схилах балки Приворотної.

Неогенові відклади представлені червонобурими щільними глинами 3 включеннями вапняковистих стяжінь. Загальна потужність глин змінюється від 6 до 14 м. Вище глин суцільним покривом залягають четвертинні відклади, потужність їх становить 6-12 м на вододілі.

Неогенові глини перекриваються лубенськими ущільненими червонувато-бурими суглинками $\left(\mathrm{Q}_{1}\right)$. Деякі дослідники виділяють неогенові глини $\mathrm{i}$ ніжньочетвертинні суглинки $\left(\mathrm{N}_{2}-\mathrm{Q}_{1}\right)$ у скіфські глини, які $є$ регіональним водотривом водоносного горизонту четвертинних відкладів.

До початку експлуатації хвостосховища новопетрівські піски були практично сухими, обводнена потужність їх не перевищувала 1,5-2,5 м. На півночі району з більш високими гіпсометричними відмітками новопетрівські піски заміщені глина- 
ми, у зв'язку з чим водоносний горизонт міг отримувати живлення лише в межах численних балок. Широкий розвиток яружно-балкової мережі, закритість пісків зверху і 3 границь не дозволили сформуватися водоносному горизонту.

У лесовидних суглинках до експлуатації хвостосховища зустрічалися окремі лінзи "верховодки" потужністю до 2-3 м, яка залягала на водотривких червоно-бурих глинах і суглинках. Тільки в балках були відмічені води балкового алювію. Широкий розвиток тут яружно-балкової мережі виключало надходження значної кількості води в четвертинні суглинки.

На території досліджень виявлено водоносний горизонт алювіальних четвертинних відкладів у заплаві р. Саксагань. Особливістю його є відсутність гідравлічного зв'язку 3 водоносним горизонтом лесоподібних суглинків, натомість можливий його зв'язок із річковими водами та водоносним горизонтом неогенових відкладів (Bagrij, Gozhik, 2005).

Отже, особливістю даного району є те, що до 1962 р. (початок будівництва гірничо-збагачувального комбінату) тут практично відсутні водоносні горизонти в четвертинних суглинках та новопетрівських пісках.

Основні джерела техногенного навантаження ПівнГЗК на водні ресурси - це хвостосховище і проммайданчик збагачувальної фабрики (Zotaeva, Kijanec, Kiseleva, Shherbatenko, 1990). По суті формування водоносних горизонтів у новопетрівських і четвертинних лесоподібних відкладах почалося внаслідок їх техногенного впливу.

Хвостосховище ПівнГЗК розташоване в балці Петриковій, у межах якої на поверхню виходять новопетрівські піски. Воно побудоване без протифільтраційного екрана.

У перші роки заповнення хвостосховища режим рівнів водоносних горизонтів тут мало відрізнявся від природного. Це пояснюється тим, що відбувалося насичення сухих новопетрівських пісків водою. До 1970 року НПР хвостосховища на перевищував покрівлі червоно-бурих глин, тому воно ще не чинило будь-якого впливу на рівневий режим водоносного горизонту четвертинних відкладів.

Із початку експлуатації хвостосховища, крім пульпи, в нього скидають господарсько-стічні води. Починаючи з 1981 року в нього скидають мінералізовані шахтні води (мінералізація до 40 г/дм $\left.{ }^{3}\right)$ хлоридно-натрієвого складу 3 підвищеним вмістом йоду, брому і важких металів (Otchet o NIR, 1991).

До скиду у хвостосховище шахтних вод (до 1981 р.) мінералізація води в ньому була найнижчою порівняно 3 хвостосховищами інших ГЗК
Кривбасу. У 1965 році мінералізація води становила 0,93 г/дм ${ }^{3}$ (початок заповнення), за переважними іонами вода сульфатно-гідрокарбонатна магнієво-натрієва. У 1968 році мінералізація зросла до 1,02-1,03 г/дм³. Починаючи з 1972-го і по 1980 рік мінералізація води у хвостосховищі була в межах 1,4-1,7 г/дм³, причому склад іiі змінився на хлоридно-сульфатний магнієво-натрієвий. У 1970 році порівняно 3 1960-м мінералізація води підвищилася приблизно в 1,5 раза, в 1,5 - 2 рази збільшився вміст сульфатів і хлоридів з одночасним зменшенням вмісту гідрокарбонатів. У 1982 році в результаті скиду шахтних вод у хвостосховищі мінералізація води зросла з 2,6 г/дм ${ }^{3}$ у січні до 5,0 г/дм ${ }^{3}$ у вересні. На кінець 1986-го вона досягла 8,7 г/дм³ ${ }^{3}$ до кінця 1987 року була 11,6 г/дм ${ }^{3}$ Нині цей показник становить 14,8 г/дм ${ }^{3}$. Вміст хлоридів близько 7,8 г/дм ${ }^{3}$, сульфатів - 1,5 г/дм ${ }^{3}$, натрію 4,5 г/дм ${ }^{3}$. За складом вода хлоридно-натрієва. Витоки 3 хвостосховища складають 7400000 м $^{3}$ на рік без урахування роботи дренажних споруд (Bulava, 1990).

Узагальнені результати аналізів проб води із 24cвердловин, обладнаних на водоносні горизонти лесоподібних суглинків та алювіальних відкладів ділянки ПівнГЗК, наведено в таблиці. Схематично на рисунку показано розташування свердловин на території ПівнГЗК. Серед 86 свердловин, по яких на даний час проводиться гідрогеологічний моніторинг, обрано 24, за якими є довгі ряди спостережень. Свердловини розташовані по всій території більш-менш рівномірно (рис.).

Найскладніша гідрогеохімічна ситуація формується поблизу свердловини № 7: без зміни типу води значно змінюються мінералізація та жорсткість. Чим далі від свердловини № 7 ситуація стає більш стабільною (св. № 15, 16, 1052), не змінюється тип води за увесь час спостережень. У той же час досить великі значення $\mathrm{pH}$ підземних вод у районі св. № 15 свідчать про посилення процесів лужного гідролізу, що зумовлено близькістю відвалів порожніх порід. У районі св. № 1126, 1138,1043 на формування хімічного складу підземних вод впливають інші техногенні об'єкти, окрім промислового майданчика (аварійна ємність, РЗФ-2). Це викликає зміни хімічного типу підземних вод (IIIa), що свідчить про метаморфізацію хімічного складу води. Найпотужнішим техногенним об'єктом є аварійна ємність, яка використовується для скидання надлишкових оборотних вод із водойми хвостосховища [Natarov, 1957]. У районі св. № 1043 на хімічний склад підземних вод впливають втрати шахтних вод із промислового майданчика РЗФ-2 (рудозбагачувальної фабрики № 2). 
Узагальнені результати аналізів проб води зі свердловин ділянки ПівнГЗК (1978 - 2015 рр.)

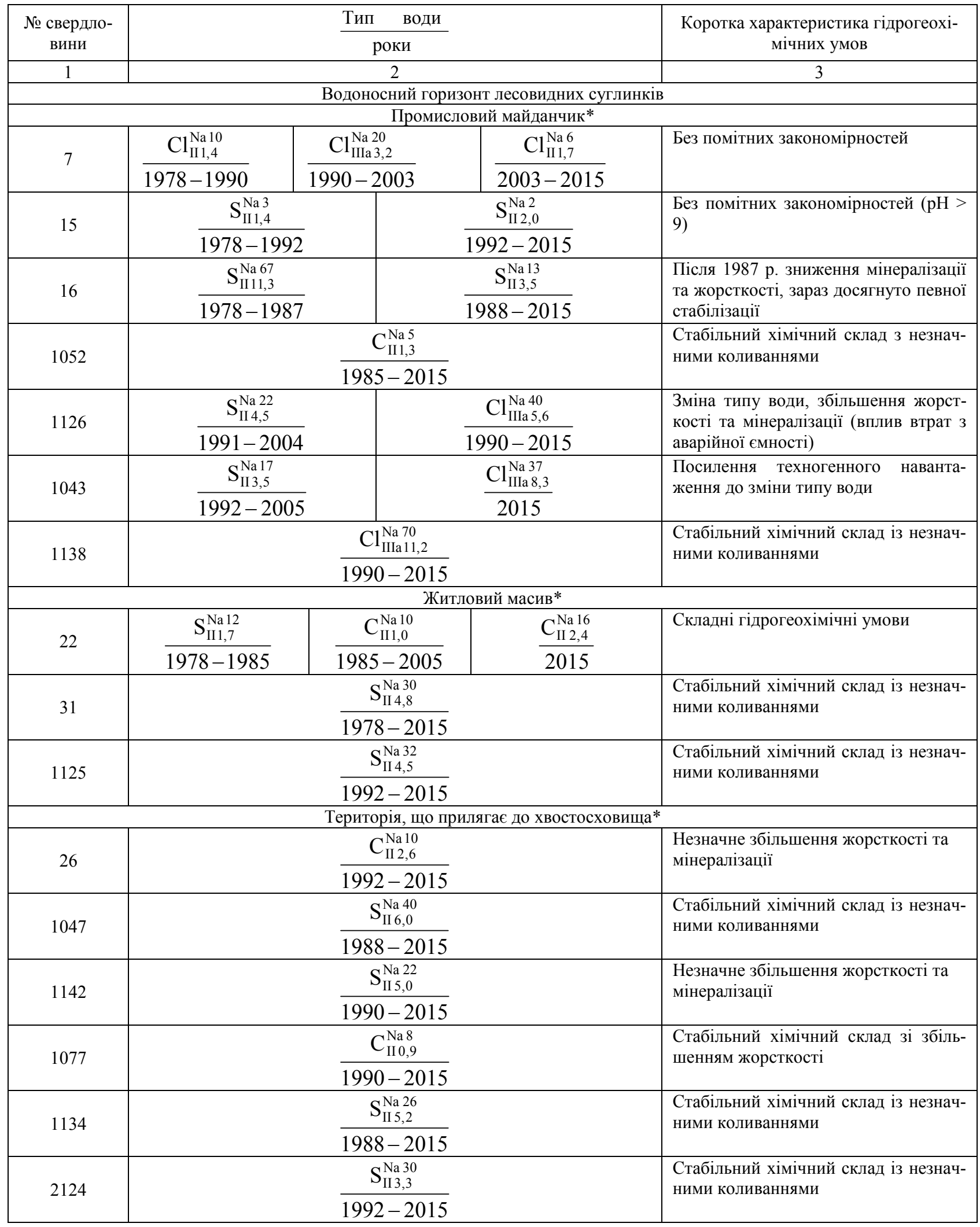


Продовження таблииі

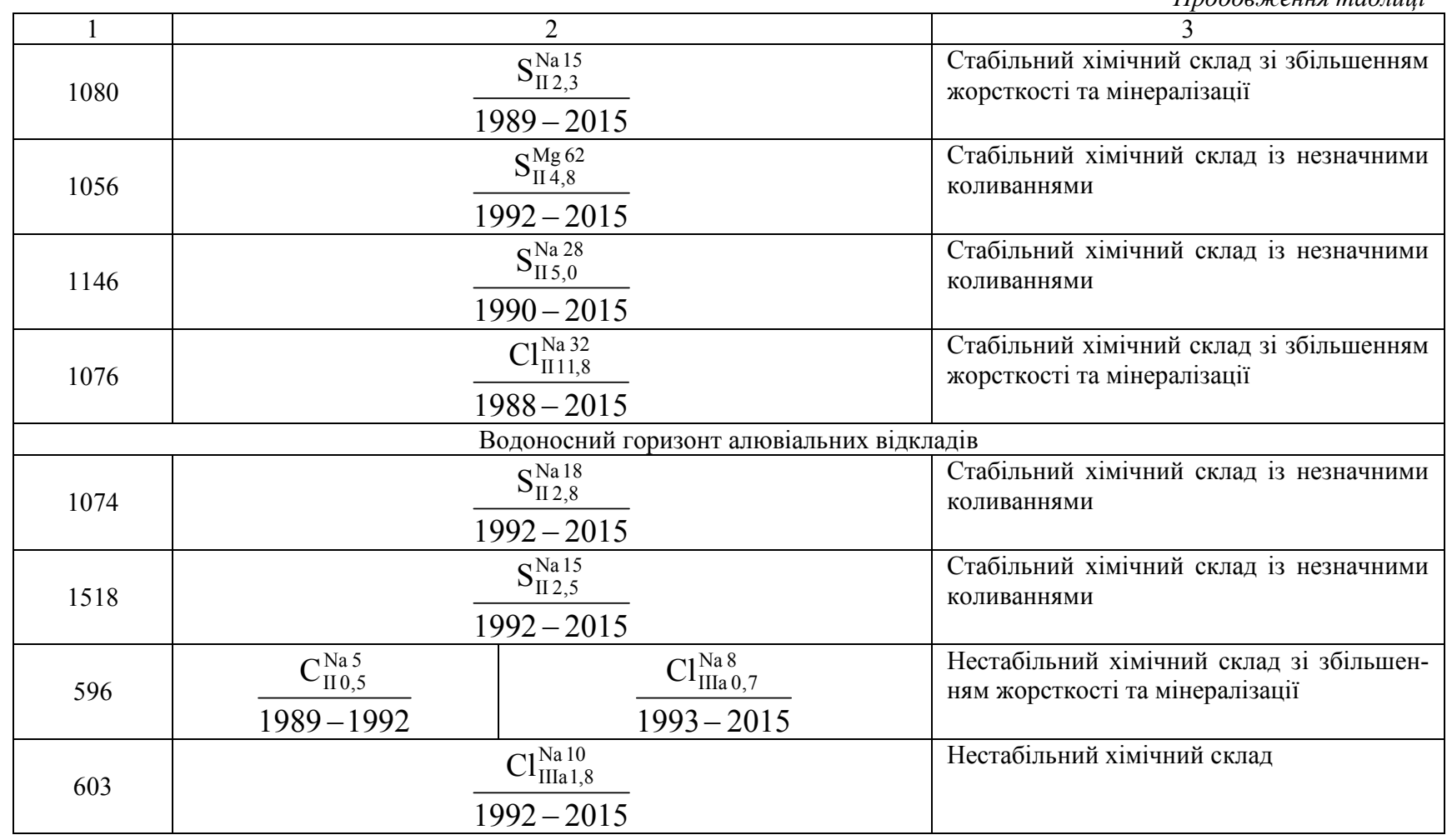

Примітка. * - Ділянки території ПівнГЗК, прийняті за районуванням Криворізької геолого-гідрогеологічної партії.

На території житлового масиву найскладніші гідрогеохімічні умови спостерігаються поблизу св. № 22: зміна типу води, мінералізації та жорсткості. У пробах води зі свердловин № 31 та 1125 тип води за весь час спостережень залишається стабільним.

На так званій «території, що прилягає до хвостосховища» гідрогеохімічні умови стабільні, незважаючи на досить велику площу, що займає ця ділянка, та різноманітність техногенних об’єктів на ній. У переважній більшості підземні води сульфатного класу, групи натрію або кальцію, другого типу. Типовою для цієї ділянки є ситуація, яка спостерігається у підземних водах поблизу св. №1080: інтенсивність збільшення мінералізації 3 1989 по 1992 рік становила 0,3 г/дм ${ }^{3}$ на рік, а 3 1992 по 2015 рік зменшилася до 0,03 г/дм ${ }^{3}$ на рік. Тобто загалом гідрогеохімічні умови на цій ділянці наближаються до стабільного стану. Однак постійно складною і нетиповою за весь час спостережень залишається гідрогеохімічна ситуація поблизу св. № 1076. Підземні води на відміну від інших, на цій ділянці - хлоридного класу з високою мінералізацією та жорсткістю.

Хімічний склад підземних вод водоносного горизонту алювіальних відкладів різноманітний: за час спостережень зустрічаються усі можливі класи вод (гідрокарбонатний, сульфатний, хлоридний). Це пов'язано із впливом на формування хімічного складу вод атмосферних опадів, надходження води 3 водоносного горизонту неогенових відкладів та p. Саксагань. Перетікання з водоносного горизонту неогенових відкладів зумовлює сульфатний клас води у підземних водах на периферії ділянки (св. № 1074, 1518). Надходження хлоридних вод із p. Саксагань зумовлює хлоридний тип підземних вод поблизу св. № 596, 603. Мінералізація підземних вод значно менша, ніж у річці $(4,1$ г/дм³ $)$, що пояснюється їх живленням атмосферними опадами. Саме таке комплексне, змішане живлення підземних вод водоносного горизонту алювіальних відкладів зумовлює їх третій тип.

Висновки. На території ПівнГЗК у підземних водах четвертинних відкладів за час спостережень (1978 - 2015) виявлено складні гідрогеохімічні умови, що спричинені потужністю техногенного впливу на хімічний склад підземних вод та його різноманітністю. В той же час станом на 2015 р. гідрогеохімічні умови на території стали більш стабільними, з окремими ділянками, на яких хімічний склад води продовжує змінюватися або є не типовим: поблизу св. № 7 (проммайданчик), 22 (житловий масив), 1076 (східна частина ділянки, що прилягає до хвостосховища), водоносний горизонт алювіальних відкладів.

Гідрогеохімічна ситуація на території Північного гірничо-збагачувального комбінату потребує подальших спостережень, аналізу та узагальнень. 


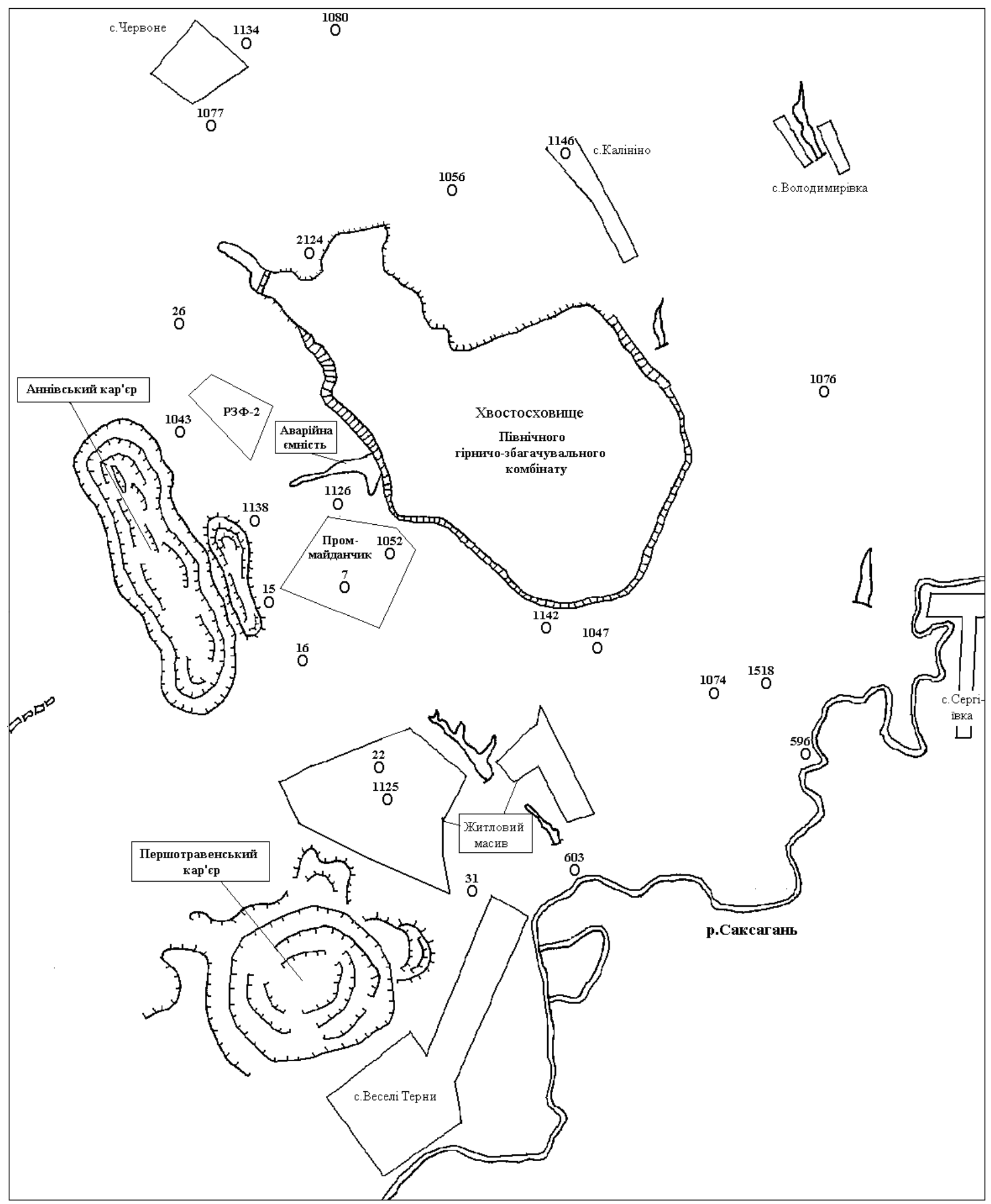

Рис. Схема території Північного гірничо-збагачувального комбінату Умовні позначення:

26 - гідрогеологічна свердловина; зверху - номер свердловини. 


\section{Бібліографічні посилання}

Bulava, L. N. 1990. Fiziko-geograficheskij ocherk territorii Krivorozhskogo gornopromyshlennogo rajona. [Physical-geographical outline the territory of Kryvyi Rih mining area]. Kryvyi Rih, Dep. in UkrNIINTI 02/11/90, 125 (in Russian).

Bagrij, I. D., Gozhik, P. F. 2005. Gidroekosistema Krivoriz'kogo basejnu - stan i naprjamki polipshennja [Hydrological ecosystem of basin of the Kryvyi Rih - condition and directions of improvement]. Kyiv, Feniks, 213 (in Ukrain).

Zotaeva, N. F., Kijanec, T. A., Kiseleva, L. Z., Shherbatenko, A. P. 1990. Vlijanie hvostohranilishha SevGOKa na kachestvo podzemnyh vod. (Racyonal'noe yspol'zovanye y ohrana nedr v chernoj metallurgy). [Influence SevGOK of the tailings on groundwater quality. (Rational utilization and conservation of mineral resources in the steel industry)]. Belgorod, VIOGEM, 65 - 67 (in Russian).

Mogilevs'kij, L. M. 2002. Vpliv tehnogenezu nadr na poverhnevi vodni ob'ekti Krivbasu. [Influence technogenic mineral resources in surface water Kryvbas. Some factors technogenesis]. Series: "The geological environment of human ecosystem". Kryvyi Rih, OKTAN-PRINT, 80 - 86 (in Ukrain).
Natarov, V.D. 1957. K voprosu ob uslovijah pitanija i stoka podzemnyh vod Krivorozhskogo bassejna NIGRI. [On the question of the conditions of supply and groundwater discharge basin of Nigro of the Kryvyi Rih]. Bulletin of scientific and technical information, 2, 102 - 105 (in Russian).

Otchet o NIR. 1991. Prognoz vlijanija hvostohranilishha SevGOKa na vodnye resursy, razrobotka tehnologicheskogo reglamenta po ohrane vodnogo basejna ot zagrjaznenija. [The forecast the impact of of the tailings SevGOK on water resources, the development of technological regulations for the protection of swimming pools of water from pollution]. NovoTEK-2, 68 (in Russian).

Sherstjuk, N. P., Evgrashkina, G. P., Vlasova, I. A. 2007. Prognoz zagrjaznenija podzemnyh vod na territorii, prilegajushhej k hvostohranilishhu Severnogo gornoobogatitel'nogo kombinata (Krivbass) [The forecast of groundwater contamination in the area adjacent to the tailings North Mining and Processing Plant (Kryvbas)]. Naukova-tehnichny magazine "Environment Ecology and Safety of Life Activity”, №6, 36 - 40 (in Russian). 